University of Nebraska - Lincoln

DigitalCommons@University of Nebraska - Lincoln

Publications from USDA-ARS / UNL Faculty

U.S. Department of Agriculture: Agricultural

Research Service, Lincoln, Nebraska

2005

\title{
Involvement of acetosyringone in plant-pathogen recognition
}

C. Jacyn Baker

USDA, jacyn.baker@ars.usda.gov

Norton M. Mock

USDA

Bruce D. Whitaker

USDA

Daniel P. Roberts

USDA, dan.roberts@ars.usda.gov

Clifford P. Rice

USDA

See next page for additional authors

Follow this and additional works at: https://digitalcommons.unl.edu/usdaarsfacpub

Part of the Agricultural Science Commons

Baker, C. Jacyn; Mock, Norton M.; Whitaker, Bruce D.; Roberts, Daniel P.; Rice, Clifford P.; Deahl, Kenneth L.; and Aver'yanov, Andrey A., "Involvement of acetosyringone in plant-pathogen recognition" (2005). Publications from USDA-ARS / UNL Faculty. 331.

https://digitalcommons.unl.edu/usdaarsfacpub/331

This Article is brought to you for free and open access by the U.S. Department of Agriculture: Agricultural Research Service, Lincoln, Nebraska at DigitalCommons@University of Nebraska - Lincoln. It has been accepted for inclusion in Publications from USDA-ARS / UNL Faculty by an authorized administrator of DigitalCommons@University of Nebraska - Lincoln. 


\section{Authors}

C. Jacyn Baker, Norton M. Mock, Bruce D. Whitaker, Daniel P. Roberts, Clifford P. Rice, Kenneth L. Deahl, and Andrey A. Aver'yanov 


\title{
Involvement of acetosyringone in plant-pathogen recognition ${ }^{\text {is }}$
}

\author{
C. Jacyn Baker ${ }^{\mathrm{a}, *}$, Norton M. Mock ${ }^{\mathrm{a}}$, Bruce D. Whitaker ${ }^{\mathrm{b}}$, Daniel P. Roberts ${ }^{\mathrm{c}}$, \\ Clifford P. Rice ${ }^{\mathrm{d}}$, Kenneth L. Deahl ${ }^{\mathrm{e}}$, Andrey A. Aver'yanov ${ }^{\mathrm{f}}$ \\ a Molecular Plant Pathology Laboratory, ARS, USDA, Beltsville, MD 20705, USA \\ ${ }^{\mathrm{b}}$ Produce Quality and Safety Laboratory, ARS, USDA, Beltsville, MD 20705, USA \\ c Sustainable Agricultural Systems Laboratory, ARS, USDA, Beltsville, MD 20705, USA \\ ${ }^{\mathrm{d}}$ Environmental Quality Laboratory, ARS, USDA, Beltsville, MD 20705, USA \\ e Vegetable Laboratory, ARS, USDA, Beltsville, MD 20705, USA \\ ${ }^{\mathrm{f}}$ Research Institute of Phytopathology, B. Vyazemy, Moscow region 143050, Russia
}

Received 22 December 2004

Available online 6 January 2005

\begin{abstract}
In this study, acetosyringone was identified as one of the major extracellular phenolics in tobacco suspension cells and was shown to have bioactive properties that influence early events in plant-bacterial pathogenesis. In our model system, tobacco cell suspensions treated with bacterial isolate Pseudomonas syringae WT $(\mathrm{HR}+)$ undergo a resistant interaction characterized by a burst in oxygen uptake several hours after inoculation. When the extracellular concentration of acetosyringone in tobacco cell suspensions was supplemented with exogenous acetosyringone, the burst in oxygen uptake occurred as much as $1.5 \mathrm{~h}$ earlier. The exogenous acetosyringone had no effect on tobacco suspensions undergoing susceptible interactions with Pseudomonas tabaci or a non-resistant interaction with a near-isogenic mutant derivative of isolate $P$. syringae WT (HR +$)$. Resistant interactions with isolate $P$. syringae WT $(\mathrm{HR}+)$ also produce an oxidative burst which oxidizes the extracellular acetosyringone. This study demonstrates that acetosyringone, and likely other extracellular phenolics, may have bioactive characteristics that can influence plant-bacterial pathogenesis. Published by Elsevier Inc.
\end{abstract}

Keywords: Oxidative burst; Oxygen uptake; Reactive oxygen; Hydrogen peroxide; Pseudomonas syringae; Pseudomonas tabaci; Nicotiana tabacum; Phenolics; Apoplast

We have been investigating extracellular phenolics that build up in plant cell suspensions and repress the oxidative burst triggered by bacterial pathogens to which the plant is resistant [1]. We report here the identity of one of the major phenolics in tobacco cell suspensions to be acetosyringone. Acetosyringone is generally considered to be a wound-induced metabolite in plants, which more than 10 years ago was shown to trigger virulence genes in the wound pathogen Agrobacterium tumefaciens [2-4]. Since then, studies of the bioactive

\footnotetext{
Abbreviations: CFU, colony-forming units; HR, hypersensitive response; RLU, relative light units.

Corresponding author. Fax: +1 3015045449.

E-mail address: bakerc@ba.ars.usda.gov (C.J. Baker).
}

influence that acetosyringone and other extracellular phenolics may have on plant pathogenesis have been scarce. In human and animal physiology, a new awareness of the wide range of regulatory effects that plant phenolics often possess has led to a renaissance in the search and study of bioactive phenolics [5-8]. Ironically in plants, the source of these compounds, little attention has been given to their potential bioactive role in influencing physiological events.

We report for the first time the bioactive effect of acetosyringone on early physiological events that take place during resistant plant-bacterial interactions. Tobacco plants that are resistant to the bean pathogen Pseudomonas syringae undergo rapid hypersensitive cell death in the leaves at the site of infection, which 
prevents spread of the pathogen. We have studied this interaction using tobacco cell suspensions [9-12]. When these cell suspensions are inoculated with $P$. syringae, a burst in oxygen uptake occurs within $4-6 \mathrm{~h}$ followed by hypersensitive cell death after $12-15 \mathrm{~h}$. The burst in oxygen uptake is unique to resistant interactions and is associated with recognition of the pathogen by the plant. By monitoring this resistant recognition response we found that increased levels of acetosyringone could reduce the response time of tobacco cells to $P$. syringae. Acetosyringone had no apparent effect on the susceptible interaction of tobacco with Pseudomonas tabaci or on interactions with a near-isogenic transposon mutant of $P$. syringae, isolate $\mathrm{B} 7(\mathrm{HR}-$ ), which cannot produce a resistant response in plants or cells. These results indicate that extracellular phenolics can significantly influence host interactions with pathogens and potentially other microbes, and warrant further examination of their bioactive properties.

\section{Materials and methods}

Chemicals. Horseradish peroxidase (P-8250) and all other chemicals were purchased from Sigma-Aldrich, St. Louis, MO, unless otherwise noted.

Tobacco cell suspensions. Suspension cells of tobacco (Nicotiana tabacum L. cv. Hicks line T4) were maintained and prepared as previously described [13]. Two-day-old tobacco cells were washed and suspended at a cell density of $0.05 \mathrm{~g} / \mathrm{ml}$ in assay buffer $\left(0.5 \mathrm{mM} \mathrm{CaCl}_{2}\right.$, $0.5 \mathrm{mM} \mathrm{K}_{2} \mathrm{SO}_{4}, 175 \mathrm{mM}$ mannitol, and $0.5 \mathrm{mM}$ Mes, $\mathrm{pH}$ 6). The cell suspensions, $25 \mathrm{ml}$, in $50-\mathrm{ml}$ beakers, were equilibrated for $0.5 \mathrm{~h}$ prior to treatment in a rotary water bath shaker at $27^{\circ} \mathrm{C}$ and $180 \mathrm{rpm}$. Bacterial or chemical treatments were added directly to the suspensions. All experiments were performed at least twice with two replicates per treatment.

Bacterial isolates. Pseudomonas syringae isolate WT $(\mathrm{HR}+)$ causes a resistant hypersensitive reaction with rapid cell death visible after 15$24 \mathrm{~h}$ when introduced into tobacco leaves or suspension cells. $P$. syringae isolate $\mathrm{B} 7(\mathrm{HR}-)$ is a mutant of isolate $P$. syringae WT $(\mathrm{HR}+)$, containing a single $\mathrm{Tn} 5$ insertion, that does not induce a hypersensitive response [9]. P. tabaci isolate 11528 is a tobacco pathogen causing susceptible disease symptoms after 3-4 days in leaves. Cultures of Pseudomonas isolates were maintained on Kings B [14] agar as previously described [13]. Medium for isolate B7 was supplemented with nalidixic acid $(25 \mu \mathrm{g} / \mathrm{ml})$ and streptomycin $(40 \mu \mathrm{g} / \mathrm{ml})$. Bacterial cultures were grown for $20 \mathrm{~h}$ in Kings B broth, centrifuged, and washed, and suspended in sterilized deionized water. Based on optical density, the concentration of the bacterial inoculum was adjusted with sterilized deionized water so that addition of about $200 \mu \mathrm{l}$ to tobacco cell suspensions would result in a final concentration of $5 \times 10^{7} \mathrm{CFU} / \mathrm{ml}$ of bacteria, unless otherwise noted. Bacterial concentrations in tobacco cell suspensions were verified periodically by dilution-plating.

UV absorbance. Samples $(1.0 \mathrm{ml})$ of cell suspensions were removed periodically and filtered through Miracloth, and the filtrate was centrifuged at $12,000 \mathrm{~g}$ for $5 \mathrm{~min}$ to remove fine particles. Absorbance readings and scans, from 200 to $400 \mathrm{~nm}$, were performed with a Beckman Model DU-650 spectrophotometer.

Extracellular antioxidant assay. The extracellular antioxidant capacity was estimated using a chemiluminescent assay that determined the quantity of $\mathrm{H}_{2} \mathrm{O}_{2}$ consumed by samples. The assay was performed using a modification of the luminol-dependent-chemiluminescent assay described previously $[1,12]$. Samples $(0.4 \mathrm{ml})$ of treated or untreated suspension cells were dispensed into tubes and placed into an EG\&G Berthold Autolumat 953 luminometer (Bad Wildbad, Germany). Two stock solutions were prepared: (A) $0.5 \mathrm{mM} \mathrm{H}_{2} \mathrm{O}_{2}$ in the same assay buffer used for cell suspensions; and (B) horseradish peroxidase, $28.8 \mathrm{U} / \mathrm{ml}$, and $1.71 \mathrm{mM}$ luminol in $1 \mathrm{M} \mathrm{NaPO}_{4}, \mathrm{pH} 7$. The luminometer first added stock solution A $(50 \mu \mathrm{l})$ followed $4.5 \mathrm{~s}$ later by stock solution $\mathrm{B}(50 \mu \mathrm{l})$. The final concentrations were $50 \mu \mathrm{M}$ $\mathrm{H}_{2} \mathrm{O}_{2}, 1.44 \mathrm{U} / \mathrm{ml}$ peroxidase, and $171 \mu \mathrm{M}$ luminol. Chemiluminescence was measured as relative light units (RLU) every $0.1 \mathrm{~s}$ for $20 \mathrm{~s}$; the maximum measurement is proportional to the $\mathrm{H}_{2} \mathrm{O}_{2}$ concentration. Standard curves were prepared with dilutions of $\mathrm{H}_{2} \mathrm{O}_{2}$ in assay buffer. Under these assay conditions, the extracellular antioxidant in each sample had sufficient time to react with the added $\mathrm{H}_{2} \mathrm{O}_{2}$; the remaining $\mathrm{H}_{2} \mathrm{O}_{2}$ reacted with luminol. The decrease in RLU in suspension samples compared to buffer controls corresponds to the $\mathrm{H}_{2} \mathrm{O}_{2}$ consumed by extracellular antioxidant in each sample and provides an estimate of the extracellular antioxidant concentration of each sample.

Oxygen uptake assay. Oxygen electrodes (Microelectrodes, Londonderry, NH, USA), and data acquisition hardware and software (National Instruments, Austin, TX, USA) were used as previously described [10]. Oxygen electrodes were calibrated to $100 \%$ in aerated buffer ( $\sim 284 \mu \mathrm{M}$ oxygen) in a water bath shaker maintained at $27{ }^{\circ} \mathrm{C}$. The multi-electrode apparatus enabled simultaneous monitoring of oxygen uptake rates in 16 beakers of tobacco cell suspensions with continuous shaking and aeration. The basic concept underlying this technique is that changes in the rate of oxygen uptake by the plant and bacterial cells will result in a change in the steady state oxygen concentration of the suspension. Based on calibration tests, at any given oxygen concentration of the assay buffer, the rate of oxygen flux from the air is known and should equal the oxygen uptake flux by the tobacco and/or bacterial cells $[10,13]$.

HPLC-UV quantification of acetosyringone. One-milliliter samples of tobacco cell suspensions were filtered through Miracloth and centrifuged at $12,000 \mathrm{~g}$ for $5 \mathrm{~min}$ prior to HPLC analysis. When not analyzed immediately, samples were flushed with $\mathrm{N}_{2}$ and stored overnight at $-20^{\circ} \mathrm{C}$. Phenolics were separated by $\mathrm{C}_{18}$ RP-HPLC using a Waters (Milford, MA) quaternary pump, autosampler, photodiode array detector, and Empower data acquisition on a Dell Pentium 4 computer. A $250 \times 4.6 \mathrm{~mm}$ i.d., $5 \mu \mathrm{m}$ Luna C18(2) analytical column (Phenomenex, Torrence, CA) was used with a binary mobile phase gradient of methanol in $0.01 \%$ aqueous phosphoric acid as previously described [15]. Aliquots, $100 \mu \mathrm{l}$, of samples were acidified with phosphoric acid $(0.1 \%)$ and placed in the autosampler using a $30 \mu \mathrm{l}$ injection volume. External standards of acetosyringone were used for quantification based on absorbance at $300 \mathrm{~nm}$.

HPLC-MS identification of acetosyringone. Atmospheric pressure ionization mass spectrometry analysis was performed on a Quattro LC benchtop triple quadrupole mass spectrometer (Micromass, Manchester, UK) using the electrospray ionization interface in the negative mode $\left(\mathrm{ES}^{-}\right)$as previously described [15]. Mass spectrometric data were acquired in the full scan mode over the $m / z$ 50-400 range. Sensitivity of the mass spectrometer was optimized using an acetosyringone standard. A Waters 2690 HPLC system using the same column and gradient as described for HPLC-UV analysis was utilized for separation of the phenolics. Samples of tobacco suspensions for mass spectroscopy were prepared as for HPLC-UV followed by acidification with phosphoric acid $(0.1 \%)$ and extraction with ethyl acetate. Dried samples were dissolved in methanol:water, $(1: 1, \mathrm{v} / \mathrm{v})$ plus $0.1 \%$ formic acid, and $20 \mu \mathrm{l}$ injected per run with a Waters autosampler.

Nuclear magnetic resonance spectroscopy. Phenolics isolated by HPLC-UV were dissolved in $0.8 \mathrm{ml} \mathrm{CD} \mathrm{CD}_{3} \mathrm{OD}$, and ${ }^{1} \mathrm{H}$ NMR spectra were acquired deuterium locked at $25^{\circ} \mathrm{C}$ using a Bruker QE $300 \mathrm{MHz}$ NMR spectrometer. Chemical shift values were assigned relative to the frequencies of residual non-deuterated water and methanol externally referenced to tetramethylsilane (TMS). 


\section{Results}

\section{Identification and extracellular accumulation of acetosyringone by tobacco cell suspensions}

Cell suspensions of tobacco (Hicks line T4) began generating an extracellular pool of phenolics within $2 \mathrm{~h}$ after being placed in fresh assay buffer [1], as determined by an increase in absorbance $(300 \mathrm{~nm})$ by the extracellular fluid (Fig. 1A). One of the major extracellular phenolics was identified as acetosyringone based on HPLC elution times, UV absorbance spectra, and $\mathrm{ES}^{-}-\mathrm{MS}$ spectra. A second phenolic, 4-hydroxyacetophenone, was identified that accumulated to $20 \%$ the levels of acetosyringone. Acetosyringone and 4-hydroxyacetophenone (Fig. 1B), respectively, eluted at 25.9 and $24.7 \mathrm{~min}$, had a broad absorbance maximum at 300 and $276 \mathrm{~nm}$, and gave a prominent $[\mathrm{M}-1]^{-}$ion at $\mathrm{m} /$ $z 195$ and 135. Authentic standards of acetosyringone (3,5-dimethoxy-4-hydroxyacetophenone) and 4hydroxyacetophenone had identical elution times, and UV and $\mathrm{ES}^{-}-\mathrm{MS}$ spectra. In addition, the ${ }^{1} \mathrm{H}$ NMR spectrum for the major tobacco phenolic eluting at 25.9 min was in accord with that recently reported for acetosyringone [16]. The concentration of extracellular acetosyringone in tobacco cell suspensions (cell density of $0.05 \mathrm{~g} / \mathrm{ml}$ ) as determined by HPLC-UV analysis increased continuously during the $10 \mathrm{~h}$ monitoring period, reaching nearly $5 \mu \mathrm{M}$ in the extracellular fluid (Fig. 1A).

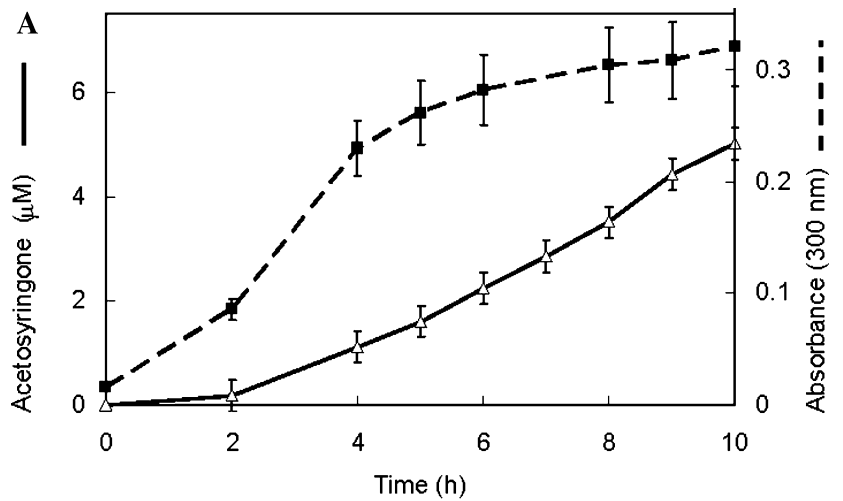

B<smiles>COc1cc(OC)cc(OC)c1</smiles><smiles>CC(=O)c1ccc(O)cc1</smiles>

acetosyringone

4-hydroxyacetophenone

Fig. 1. The accumulation of extracellular phenolics in tobacco cell suspensions. (A) The relative amount of extracellular phenolics was monitored by absorbance $300 \mathrm{~nm}$ of the extracellular fluid. Acetosyringone was quantified by HPLC-UV analysis. Tobacco cells, $0.05 \mathrm{~g} / \mathrm{ml}$, were incubated in assay buffer, $\mathrm{pH} 6$, on a rotating water bath at $27^{\circ} \mathrm{C}$. See Materials and methods for further details. (B) The structures of acetosyringone and 4-hydroxyacetophenone.
Effect of acetosyringone on tobacco-suspension-celll bacteria interactions

Exogenous acetosyringone accelerated the resistant interaction of the tobacco suspension cells with $P$. syringae WT $(\mathrm{HR}+)$, but had little apparent effect on the susceptible interaction with $P$. tabaci or the non-resistant interaction with $P$. syringae $\mathrm{B} 7(\mathrm{HR}-)$. This was determined by monitoring the oxygen uptake by tobacco cell suspensions $(0.05 \mathrm{~g} / \mathrm{ml})$ inoculated with the different bacteria $\left(5 \times 10^{7} \mathrm{CFU} / \mathrm{ml}\right)$ (Fig. $\left.2 \mathrm{~A}\right)$. Tobacco cell suspensions treated with $P$. syringae isolate WT $(\mathrm{HR}+)$ undergo a significant oxygen uptake response between 5 and $7 \mathrm{~h}$ in the absence of exogenous acetosyringone, with a midpoint time around $6.5 \mathrm{~h}$. During this period, the rate of oxygen uptake by this treatment slightly more than doubled, increasing from $8 \mu \mathrm{M} / \mathrm{min}$ to approximately $20 \mu \mathrm{M} / \mathrm{min}$. When acetosyringone was added to these suspensions at final concentrations of 50, 100, and $200 \mu \mathrm{M}$, the midpoint time of the oxygen uptake response decreased to $6,5.6$, and $4.9 \mathrm{~h}$, respectively (Fig. 2A). The magnitude of the increase in the rate of oxygen uptake, however, remained about the same at 10

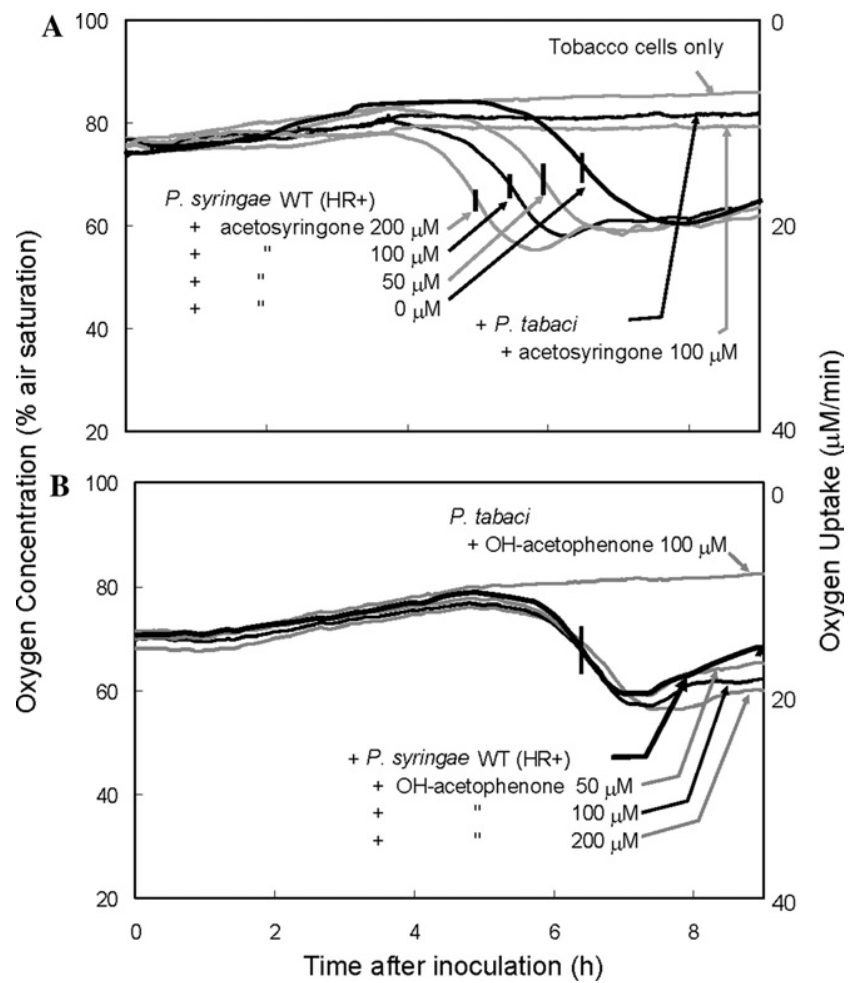

Fig. 2. Measurement of oxygen uptake by tobacco suspension cells, $0.05 \mathrm{~g} / \mathrm{ml}$, treated with $P$. syringae isolate WT $(\mathrm{HR}+)$ or $P$. tabaci. The steady state concentration of oxygen (left axis) in suspensions is monitored every $15 \mathrm{~s}$ using an oxygen electrode and is directly related to the rate of oxygen uptake (right axis). Acetosyringone (A) or 4 hydroxyacetophenone (B) was added at $-0.5 \mathrm{~h}$ at the concentrations indicated. Bacteria, $5 \times 10^{7} \mathrm{CFU} / \mathrm{ml}$, were added at $0 \mathrm{~h}$. See Materials and methods for further details. 
$12 \mu \mathrm{M} / \mathrm{min}$. In contrast, the addition of acetosyringone had no effect on oxygen uptake by susceptible interactions of tobacco cell suspensions treated with $P$. tabaci (Fig. 2A). Similarly, the addition of acetosyringone had no effect on oxygen uptake in interactions of tobacco suspensions with strain $P$. syringae $\mathrm{B} 7(\mathrm{HR}-)$, a near-isogenic mutant derived from $P$. syringae isolate WT (HR+), which does not cause increased oxygen uptake or subsequent cell death (data not shown).

The reduction in timing for the oxygen uptake response caused by exogenous acetosyringone appears to be related to the specific chemical structure acetosyringone rather than its antioxidant properties. This was determined by substituting 4-hydroxyacetophenone, a structurally related phenolic with similar antioxidant characteristics, for acetosyringone in the experiments described above (Fig. 2B). There was no significant change in the midpoint time of the oxygen uptake response of tobacco cell suspensions treated with $P$. syringae WT $(\mathrm{HR}+)$ containing a final concentration of $0,50,100$, and $200 \mu \mathrm{M}$ of exogenous 4-hydroxyacetophenone. The addition of 4-hydroxyaceteophenone had no effect on susceptible interactions with $P$. tabaci (Fig. 2B), or on treatments with the near-isogenic mutant strain $P$. syringae B7 (HR-) (data not shown). The concentrations of exogenous acetosyringone and 4-hydroxyacetophenone added to the cell suspensions in these experiments were monitored periodically by HPLC-UV to ensure that the extracellular levels of these compounds remained relatively constant and that these compounds were not metabolized or oxidized significantly.

\section{Redox sensitivity of acetosyringone}

The extracellular concentration of acetosyringone decreases during the oxidative burst [11] that accompanies resistant interactions. In susceptible interactions, in which no oxidative burst occurs, the acetosyringone concentration continually increases. This was determined by measuring the extracellular antioxidant capacity (Fig. 3A) and extracellular acetosyringone (Fig. 3B) of tobacco cell suspensions $(0.05 \mathrm{~g} / \mathrm{ml})$ inoculated with different bacteria $\left(5 \times 10^{7} \mathrm{CFU} / \mathrm{ml}\right)$. In resistant interactions of tobacco cell suspensions inoculated with $P$. syringae $\mathrm{WT}(\mathrm{HR}+)$, an oxidative burst occurred after $4 \mathrm{~h}$ as detected by a decrease in extracellular antioxidant capacity of the samples (Fig. 3A). This decrease in antioxidant capacity lasted about $2 \mathrm{~h}$ after which time the antioxidant capacity began to increase again. During this same period HPLC-UV analysis of extracellular fluid showed that the concentration of acetosyringone decreased followed by a recovery (Fig. 3B). In susceptible interactions of tobacco cell suspensions inoculated with $P$. tabaci (Figs. 3A and B), no oxidative burst was detected and both the extracellular antioxidant capacity and acetosyringone concentration continued

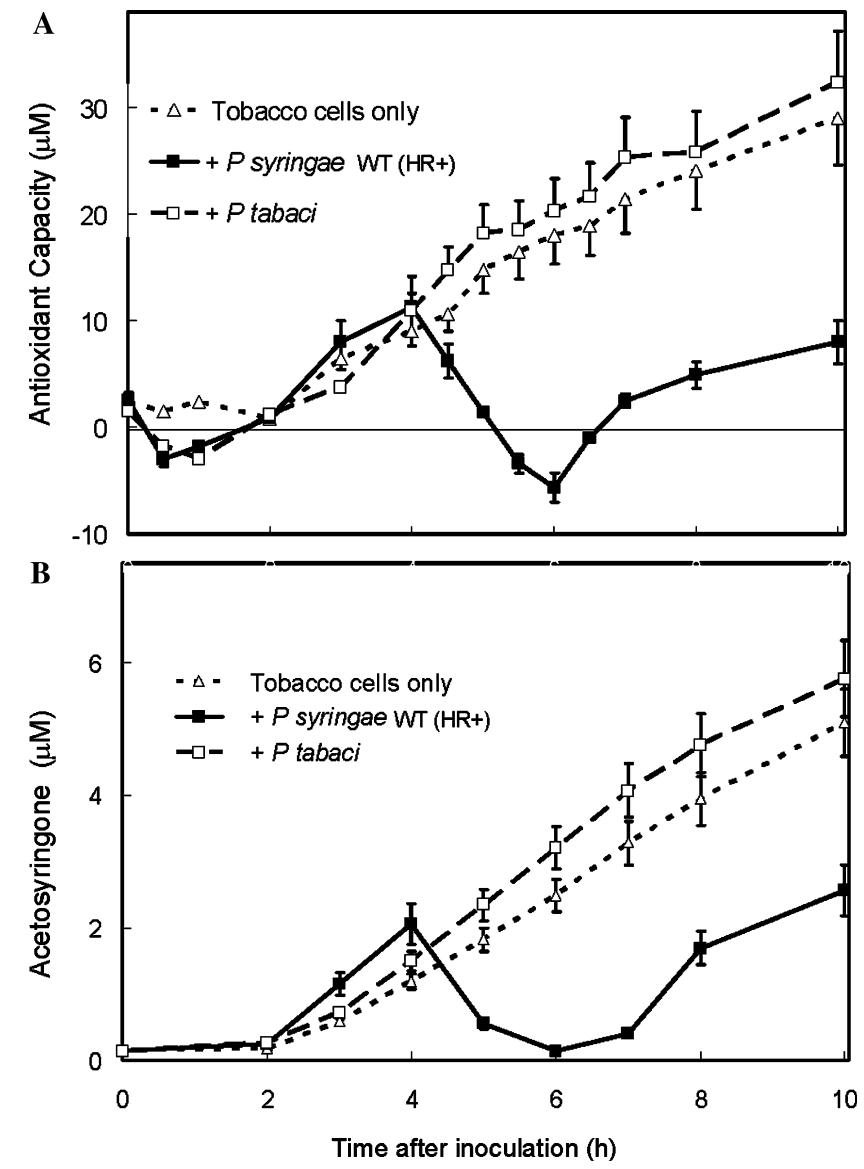

Fig. 3. Time course monitoring changes in extracellular antioxidant capacity (A) and extracellular acetosyringone concentration (B) in tobacco cell suspensions $(0.05 \mathrm{~g} / \mathrm{ml})$ treated with isolates of Pseudomonas $\left(5 \times 10^{7} \mathrm{CFU} / \mathrm{ml}\right)$. Samples $(0.4 \mathrm{ml})$ of cell suspensions were removed and assayed for antioxidant capacity using a chemiluminescent assay, which measures the concentration of hydrogen peroxide that the sample can scavenge. Acetosyringone concentrations in samples of cell suspensions were analyzed by HPLC-UV. See Materials and methods for further details.

to increase. Similar results were found with untreated tobacco cell suspensions (Figs. 3A and B) and suspensions treated with strain $P$. syringae $\mathrm{B} 7(\mathrm{HR}-$ ) (data not shown).

The decrease in acetosyringone during this oxidative burst in resistant interactions indicates that acetosyringone may function as an antioxidant. It could be used as a substrate for cell wall peroxidases to scavenge the hydrogen peroxide produced during the oxidative burst. To verify this, acetosyringone $(100 \mu \mathrm{M})$ was incubated in $50 \mathrm{mM}$ Mes buffer, $\mathrm{pH}$ 6, with horseradish peroxidase and $\mathrm{H}_{2} \mathrm{O}_{2}$, the latter of which was added in $10 \mu \mathrm{M}$ increments (Fig. 4A). An incremental decrease in the absorbance scan (200-400 $\mathrm{nm})$ of the reaction mixture could be observed after each addition of $\mathrm{H}_{2} \mathrm{O}_{2}$ (Fig. 4A). The decrease in acetosyringone concentration was verified by HPLC-UV analysis. Similar results were found for 4-hydroxyacetophenone (Fig. 4B). To verify that 


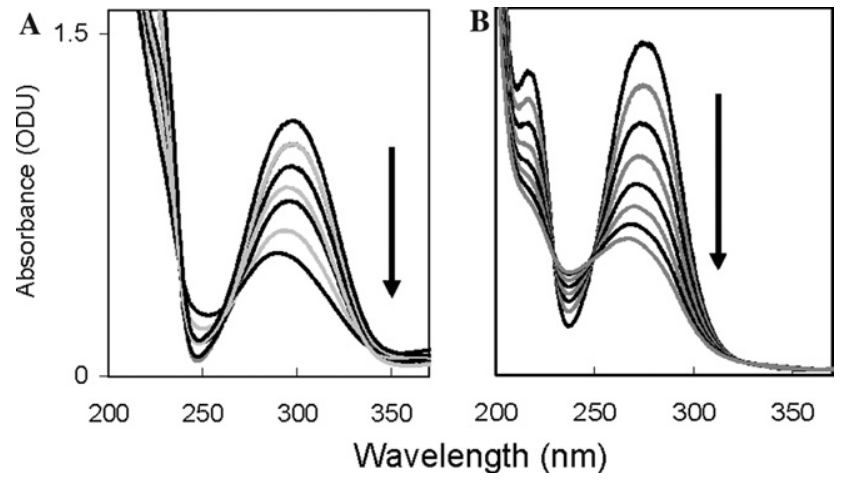

Fig. 4. Oxidation of acetosyringone (A) and 4-hydroxyacetophenone (B) by hydrogen peroxide and horseradish peroxidase. UV scans show progressive oxidation, as shown by arrows, of each compound by hydrogen peroxide and horseradish peroxidase. Reaction mixtures containing the phenolics, $100 \mu \mathrm{M}$, and $0.07 \mathrm{U}$ of peroxidase were scanned after increments, $10 \mu \mathrm{M}$, of hydrogen peroxide were added. See Materials and methods for other details.

the tobacco suspensions could utilize these phenolics in a similar manner, exogenous $\mathrm{H}_{2} \mathrm{O}_{2},(100 \mu \mathrm{M})$, was added directly to tobacco suspensions containing $100 \mu \mathrm{M}$ of either exogenous acetosyringone or 4hydroxyacetophenone. The loss of both phenolic compounds occurred only after $\mathrm{H}_{2} \mathrm{O}_{2}$ was added and was similar to that observed during incubation with horseradish peroxidase (data not shown).

\section{Increased accumulation of acetosyringone due to treatment with bacteria}

The rate and magnitude of acetosyringone accumulation in the extracellular fluid of tobacco suspensions increased in the presence of bacteria. This was most easily observed with tobacco cell suspensions treated with either P. tabaci or P. syringae strain B7 (HR-). As demonstrated above, neither of these treatments induced an oxidative burst that oxidized phenolics. When tobacco cell suspensions were incubated with either of these bacteria for $6 \mathrm{~h}$, the concentration of extracellular acetosyringone increased as the bacterial concentration of the inoculum increased (Fig. 5A). At concentrations of $5 \times 10^{8} \mathrm{CFU} / \mathrm{ml}$ the amount of acetosyringone had increased nearly 2- and 3-fold for P. syringae B7 (HR-) and $P$. tabaci, respectively, relative to tobacco cells only. The bacterial concentrations of treated cell suspensions were checked by dilution-plating and found not to change substantially during incubation (data not shown).

A similar increase in extracellular acetosyringone could be detected in tobacco cell suspensions treated with isolate $P$. syringae $\mathrm{WT}(\mathrm{HR}+)$ prior to the oxidative burst as shown in Fig. 3B at $4 \mathrm{~h}$. Tobacco cell suspensions were treated with increasing concentrations of $P$. syringae WT $(\mathrm{HR}+)$ and the extracellular concen-
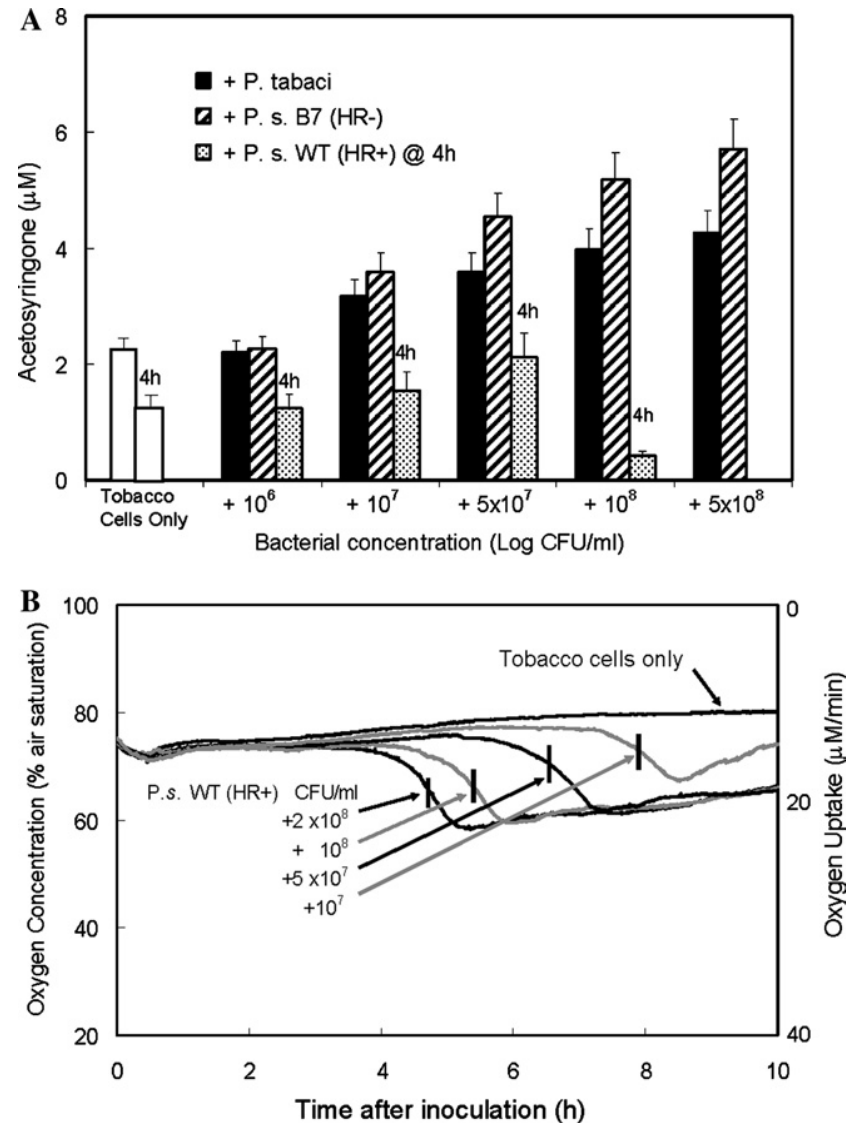

Fig. 5. Effect of increased bacterial concentration on the extracellular accumulation of acetosyringone and onset of the oxygen uptake response in tobacco cell suspensions. (A) Tobacco suspensions, $0.05 \mathrm{~g} /$ $\mathrm{ml}$, were treated with different concentrations of $P$. tabaci, $P$. syringae strain B7 (HR-), or P. syringae WT $(\mathrm{HR}+)$. The concentration of extracellular acetosyringone was determined by HPLC-UV. The values for suspensions treated with $P$. tabaci and $P$. syringae strain B7 (HR-) were taken after $6 \mathrm{~h}$ incubation. The values for treatments with $P$. syringae WT $(\mathrm{HR}+)$ were taken after $4 \mathrm{~h}$ to avoid interference by the oxidative burst. (B) The onset of the oxygen uptake response by tobacco cell suspensions treated with different concentrations of $P$. syringae strain WT $(\mathrm{HR}+)$. The steady state concentration of oxygen (left axis) in suspensions is monitored every $15 \mathrm{~s}$ using an oxygen electrode and is directly related to the rate of oxygen uptake (right axis). See Materials and methods for other details.

tration of acetosyringone after $4 \mathrm{~h}$ was compared (Fig. $5 \mathrm{~A})$. At bacterial concentrations of up to $5 \times 10^{7} \mathrm{CFU} /$ $\mathrm{ml}$ the accumulation of acetosyringone was greater than with untreated cell suspensions. Above this bacterial concentration, the onset of the oxidative burst occurred earlier (data not shown) and oxidized the induced acetosyringone. Interestingly, increasing the bacterial concentration of isolate $P$. syringae WT $(\mathrm{HR}+)$ added to tobacco suspension cells decreased the time prior to the oxygen uptake burst (Fig. 5B) similar to the effect of increased acetosyringone. The midpoint time of the oxygen uptake burst decreased from 7.8 to $4.6 \mathrm{~h}$ as inoculum increased from $1 \times 10^{7}$ to $2 \times 10^{8} \mathrm{CFU} / \mathrm{ml}$. 


\section{Discussion}

This study demonstrates the interplay between plant extracellular phenolics and bacterial interactions with plant cells. This is the first report to demonstrate a specific example in which an extracellular phenolic, namely acetosyringone, influences the timing of an early physiological event associated with resistant plant-bacterial interactions. Several lines of evidence support this. First, acetosyringone was identified as one of the extracellular phenolics that accumulated in the tobacco cell suspensions (Fig. 1). Second, increasing the concentration of extracellular acetosyringone through exogenous addition of this compound to tobacco cell suspensions reduced the time after inoculation that the oxygen uptake burst occurred in resistant interactions with $P$. syringae WT $(\mathrm{HR}+)$ (Fig. 2). Third, as the concentration of the bacterial inoculum increased: (a) the rate and magnitude of extracellular acetosyringone accumulation in tobacco suspensions increased (Fig. 5A) and (b) there was a reduction of the time after inoculation that the oxygen uptake burst occurred in resistant interactions of tobacco cells with $P$. syringae WT $(\mathrm{HR}+)$ (Fig. 5B).

This study also demonstrated that the concentration of extracellular acetosyringone is redox sensitive in that it is oxidized during periods of oxidative stress. This was shown in resistant interactions of tobacco cell suspensions with $P$. syringae WT $(\mathrm{HR}+)($ Fig. 3$)$ in which the concentration of acetosyringone decreased during the oxidative burst. This finding leads to two implications. One, the bioactive influence of extracellular acetosyringone on resistant interactions needs to occur prior to the oxidative burst. Two, susceptible interactions, which do not undergo an oxidative burst, maintain higher levels of extracellular acetosyringone throughout this early period which could have a bioactive influence at subsequent stages of the plant-bacterial interaction.

Changes in the extracellular acetosyringone concentration through exogenous addition of this compound had no detectable effect on oxygen uptake by susceptible interactions of tobacco cells with $P$. tabaci. Similar results were obtained with $P$. syringae $\mathrm{B} 7(\mathrm{HR}-)$, which is a near-isogenic mutant of isolate $\mathrm{WT}(\mathrm{HR}+)$, that does not cause the oxygen burst in tobacco suspensions. This strongly suggests that the effect of acetosyringone observed in this study was specifically related to bacteria involved in the resistant interaction. The effect of acetosyringone did not appear to be strictly due to its antioxidant nature since a structurally related phenolic, 4-hydroxyacetophenone that has similar antioxidant activity (Fig. 4B), did not affect the oxygen uptake response during resistant plant-bacterial interactions (Fig. 2B).

The disparity in the concentration of exogenous acetosyringone, 50-200 $\mu \mathrm{M}$ (Fig. 2A), needed to affect the timing of the oxygen uptake response and the amounts present with bacteria, 2-6 $\mu \mathrm{M}$ (Fig. 3), are likely due in part to the volume of the extracellular fluid present in suspension cells. The tobacco cell volume is about $5 \%$ of the suspension volume; i.e., cell/fluid ratio is about $1 / 20$. Only a fraction of this cell volume is composed of the cell wall region where the critical plant-bacterial interactions take place. All of the acetosyringone produced by the tobacco cell must travel through this region. It seems reasonable that the concentration of the acetosyringone experienced by bacteria in this cell wall region could be much greater than would be detected after dilution into the total suspension fluid; 20- to 50fold dilution would suggest that the cell wall concentration of acetosyringone could easily reach the 50-200 $\mu \mathrm{M}$ concentrations.

Further studies will be required to determine the mechanism by which acetosyringone causes the effects described in this study. It is feasible that it is similar to that suggested for the stimulation of plant transformation via $A$. tumefaciens [2]; the mechanism reportedly involves phenol-binding proteins produced by Agrobacterium that detect acetosyringone and subsequently activate other virulence genes $[3,4]$. The sensitivity of the extracellular accumulation of acetosyringone to exogenous stimuli was also mentioned briefly in two related studies in which treatments with a fungal cellulase or other fungal extracts affected the acetosyringone concentrations in suspension cells of tobacco [17] and Hyoscyamus albus [18], respectively.

This report demonstrates that extracellular phenolics can play a bioactive role in plant-microbial interactions in addition to the traditional antioxidant and secondary wall reinforcing roles. We found that the profile of extracellular phenolics was very responsive to changes in the status of the suspension cells. It is likely that other phenolics will be found to be bioactive. The use of the relatively non-invasive oxygen uptake response provides a means to detect bioactivity during early phases of the resistant plant-bacterial response. The finding that these extracellular phenolics are redox sensitive suggests that their influence would be negated during times of oxidative stress associated with resistant interactions. The phenolics would be oxidized and greatly decreased in concentration. In susceptible interactions this oxidative stress is as prevalent allowing bioactive phenolics to accumulate to higher concentrations.

\section{Acknowledgments}

We thank Dr. Walter F. Schmidt and Mrs. Ute Klingebiel, USDA, ARS, Environmental Quality Laboratory, for acquisition of the ${ }^{1} \mathrm{H}$ NMR spectra. Mention of a trade name, proprietary product, or vendor does not constitute a guarantee of the product by the United 
States Department of Agriculture and does not imply its approval to the exclusion of other vendors that may also be suitable.

\section{References}

[1] C.J. Baker, N.R. O’Neill, K. Deahl, J. Lydon, Continuous production of extracellular antioxidants in suspension cells attenuates the oxidative burst detected in plant microbe interactions, Plant Physiol. Biochem. 40 (2002) 641-644.

[2] G.W. Bolton, E.W. Nester, M.P. Gordon, Plant phenolic compounds induce expression of the Agrobacterium tumefaciens loci needed for virulence, Science 232 (1986) 983-985.

[3] K. Lee, M.W. Dudley, K.M. Hess, D.G. Lynn, R.D. Joerger, A.N. Binns, Mechanism of activation of Agrobacterium virulence genes: identification of phenol-binding proteins, Proc. Natl. Acad. Sci. USA 89 (1992) 8666-8670.

[4] Y.W. Lee, S. Jin, W.S. Sim, E.W. Nester, Genetic evidence for direct sensing of phenolic compounds by the VirA protein of Agrobacterium tumefaciens, Proc. Natl. Acad. Sci. USA 92 (1995) $12245-12249$.

[5] A.J. Parr, G.P. Bolwell, Phenols in the plant and in man. The potential for possible nutritional enhancement of the diet by modifying the phenols content or profile, J. Sci. Food Agric. 80 (2000) 985-1012.

[6] K. Robards, Strategies for the determination of bioactive phenols in plants, fruit and vegetables, J. Chromatogr. A 1000 (2003) 657691.

[7] J.A.T. Pennington, Food composition databases for bioactive food components, J. Food Compos. Anal. 15 (2002) 419-434.

[8] G. Loo, Redox-sensitive mechanisms of phytochemical-mediated inhibition of cancer cell proliferation, J. Nutr. Biochem. 14 (2003) 64-73.
[9] C.J. Baker, M.M. Atkinson, A. Collmer, Concurrent loss in Tn5 mutants of Pseudomonas syringae pv. syringae of the ability to induce the hypersensitive response and host plasma membrane $\mathrm{K}+/ \mathrm{H}+$ exchange in tobacco, Phytopathology 77 (1987) 12681272.

[10] C.J. Baker, N.M. Mock, K. Deahl, J. Domek, Monitoring the rate of oxygen consumption in plant cell suspensions, Plant Cell Tissue Organ Cult. 51 (1997) 111-117.

[11] C.J. Baker, N.R. O'Neill, L.D. Keppler, E.W. Orlandi, Early Responses during plant-bacteria interactions in tobacco cell suspensions, Phytopathology 81 (1991) 1504-1507.

[12] J. Glazener, E.W. Orlandi, G.L. Harmon, C.J. Baker, An improved method for monitoring active oxygen in bacteriatreated suspension cells using luminol-dependent chemiluminescence, Physiol. Mol. Plant Pathol. 39 (1991) 123-133.

[13] C.J. Baker, N. Mock, K.L. Deahl, B. Bailey, D.P. Roberts, Oxidative metabolism in plant/bacteria interactions: Characterization of the oxygen uptake response of bacteria, Physiol. Mol. Plant Pathol. 59 (2001) 17-23.

[14] O.D. Dhingra, J.B. Sinclair, Basic Plant Pathology Methods, CRC Press, Boca Raton, 1985.

[15] B.D. Whitaker, J.R. Stommel, Distribution of hydroxycinnamic acid conjugates in fruit of commercial eggplant (Solanum melongena L.) cultivars, J. Agric. Food Chem. 51 (2003) 3448-3454.

[16] J. Blount, S. Masoud, L. Sumner, D. Huhman, R. Dixon, Overexpression of cinnamate 4-hydroxylase leads to increased accumulation of acetosyringone in elicited tobacco cell-suspension cultures, Planta 214 (2002) 902-910.

[17] D.R. Threlfall, I.M. Whitehead, Co-ordinated inhibition of squalene synthetase and induction of enzymes of sesquiterpenoid phytoalexin biosynthesis in cultures of Nicotiana tabacum, Phytochemistry 27 (1988) 2567-2580.

[18] M.G. Miguel, J.G. Barroso, Accumulation of stress metabolites in cell suspension cultures of Hyoscyamus albus, Phytochemistry 35 (1994) 371-375. 